Journal of Southeast Asian

Volume 15

Issue 2 Voices from the Field: Centering

Southeast Asian Americans through Policy,

Article 7

Practice, and Activism

2020

\title{
From the Flatlands of Oakland to the Ivory Towers of Higher Education: A Counter-Narrative of a Southeast Asian Refugee
}

Van T. Lac

University of Texas at San Antonio, van.lac@utsa.edu

Follow this and additional works at: https://docs.lib.purdue.edu/jsaaea

Part of the Bilingual, Multilingual, and Multicultural Education Commons, and the Humane Education Commons

\section{Recommended Citation}

Lac, Van T. (2020) "From the Flatlands of Oakland to the Ivory Towers of Higher Education: A CounterNarrative of a Southeast Asian Refugee," Journal of Southeast Asian American Education and Advancement. Vol. 15 : Iss. 2, Article 7.

DOI: $10.7771 / 2153-8999.1206$

Available at: https://docs.lib.purdue.edu/jsaaea/vol15/iss2/7

This document has been made available through Purdue e-Pubs, a service of the Purdue University Libraries. Please contact epubs@purdue.edu for additional information.

This is an Open Access journal. This means that it uses a funding model that does not charge readers or their institutions for access. Readers may freely read, download, copy, distribute, print, search, or link to the full texts of articles. This journal is covered under the CC BY-NC-ND license. 


\section{From the Flatlands of Oakland to the Ivory Towers of Higher Education: A Counter-Narrative of a Southeast Asian Refugee}

\section{Cover Page Footnote}

I would like to thank Drs. Peter Keo and Loan Dao for inviting me to join this special issue. A special thank you to all the adults, mentors, and senior scholars who have buoyed me along the way. 


\title{
JSAAEA Journal of Southeast Asian American
Education and Advancement
}

Vol. 15 Iss. 2 Special Issue (2020) www.JSAAEA.org

\section{From the Flatlands of Oakland to the Ivory Towers of Higher Education: A Counter-Narrative of a Southeast Asian Refugee}

\author{
Van T. Lac \\ University of Texas at San Antonio
}

\begin{abstract}
This counter-narrative exposes the themes of (dis)placement and (in)visibility that the author has encountered as a Southeast Asian refugee navigating the educational systems in K12 public schools and higher education. The author begins with a snapshot of adolescence growing up in a low-income community in Oakland, California, highlighting her observations as a Southeast Asian refugee youth and the plight of her peers. The latter part of the essay surfaces her experiences existing in higher education contexts where the model minority myth shapes in explicit and veiled ways how she traverses spaces as a Southeast Asian refugee in college, graduate studies, and the academy.
\end{abstract}

Keywords: Southeast Asian, Model minority myth, Oakland, refugee, Vietnamese youth

\section{Introduction}

Giving birth to her second child in a cold and sterile hospital in Hong Kong, my mother, at the time residing at the Kai Tak refugee camp, endured glares of disdain and resentment from the nurses and doctors that tended to her at the hospital. In their eyes, my mother represented another one of those "boat people" siphoning scarce resources from the deserving citizens of Hong Kong. I open this counter-narrative with this scene of my birth because I feel obligated to acknowledge how much of my identity as a refugee continually shapes me, grappling with themes of (dis)placement and (in)visibility, from my childhood experiences growing up in the flatlands of Oakland, California to my journey in the academy.

\section{From the Flatlands of Oakland}

As a refugee child, much of my adolescence required traversing the generational, educational, linguistic, and cultural divides between my parents and us children, the 1.5 generation, who were

\footnotetext{
(c)

SDRERIIGHISRESERNEDR Readers are free to copy, display, and distribute this article, as long as the work is attributed to the author(s) and the Journal of Southeast Asian American Education \& Advancement, it is distributed for non-commercial purposes only, and no alteration or transformation is made in the work. More details of this Creative Commons license are available at http://creativecommons.org/licenses/by-nc-nd/3.0/. All other uses must be approved by the author(s) or JSAAEA. Journal of Southeast Asian American Education \& Advancement, Vol. 15. Iss. 2. (2020) ISSN: 2153-8999
} 
not quite fully American and not quite fully entrenched in the traditions of our homeland. Before the affluent gentrifiers, hipster coffee shops, and bandwagon Dub Nation fans encroached on Oakland, my family settled on the east side of The Town in the early 1980s as a part of a large influx of Southeast Asian refugees fleeing political persecution from Vietnam, Cambodia, and Laos. Growing up, I witnessed my ethnic-Chinese father and Vietnamese mother, both possessing only a middle school education from Vietnam, struggle to provide the basic needs to my four siblings and me-all in a new land where they did not speak the language, nor understand the culture.

Life for me revolved around discerning what was sanctioned as acceptable or not in our actions or behaviors at the intersections of home, neighborhood, school, and community. For instance, my mother was appalled at the tradition of trick-or-treating during Halloween; she could not wrap her mind around knocking on strangers' doors and then asking for candy, only to return home and consume these sweets potentially laced with who knows what. In another case, somehow my parents believed it was completely reasonable for my older sister and me, in the third and first grade respectively, to walk two long blocks to school without adult supervision, passing the liquor store on the corner and drug dealers hustling in their hoopties. As a mom now, I cautiously walk my 7-year-old and preschooler to school every morning, protectively holding their hands as we cross the tranquil, tree-lined streets of our suburban neighborhood. I understand now, years later, that some of my parents' decisions were born out of necessity and grounded in their understandings of childhood. For one, my parents did not have the privilege of being at home all the time to send and receive us because they were preoccupied with building a new and better life for their children. I also interpret that for my parents' conceptions of adulthood, mired in strife and struggle, particularly in war-torn Vietnam, start much earlier in life.

Due to the order of our siblings and cultural expectations of girls, my older sister and I were left with a lot more responsibilities than perhaps the average American child. I recall one morning several Mormons knocked on our door trying to proselytize; neither my mom, grandmother nor aunt could communicate with them, so as a third-grader, I told these white men that we were not interested in their religion. In that moment, it felt good being able to help my family with my English; however, as an adolescent, translating letters, making phone calls, or speaking on behalf of my parents represented another undue burden placed upon me as an immigrant child - another example of how different I am and my childhood is from my peers who had English-speaking or American parents.

Maneuvering in and through K12 public schools and my neighborhood in the flatlands of Oakland would require a distinct set of navigational skills as well, particularly as a Southeast Asian female. I attended Roosevelt Junior School, which served 100\% low-income, students of color: primarily Black, Latinx, Southeast Asian and Pacific Islanders. School was not safe by any stretch of the imagination. In class, you could get clowned at any second. Down the street at San Antonio park, students would organize fights after school or jump other kids. There was more structure and order at a Black Friday sale at Walmart than any class I attended in junior high. With the exception of a few, most teachers did not have the relational trust to establish safe and nurturing spaces. For me, as a generally quiet and introspective student, I often avoided the fray because I knew instinctively to not bring attention to myself, let alone, talk shit. It was in junior high school that I began to notice a proliferation of gangs: Black kids joined the Rolling 20s while the Latinx students claimed red, and Southeast Asian youth banged blue.

As a thirteen-year-old, I knew better than to join a gang, but in retrospect, I completely understand why my Southeast Asian peers initiated into gang life. Gangs offered young people the 
safety and solidarity that no school teacher nor classroom could provide. Despite the disapproval of their parents, my peers who joined gangs also struggled with the same divides that I toiled with in my own household. Whether they were Khmer, Laotian, Mien, an ethnic minority from the hilltribes of Laos, or boat people like my family, we all shared a common struggle: trying to survive while being Southeast Asian refugee kids, feeling somewhat estranged both at home and at school. In my mind, teachers and staff at Roosevelt Junior High School were either blind or ignorant to the hardships of Southeast Asian refugee youth: a parent struggling with a gambling addiction; a father with unmanaged mental health issues lashing out violently at his wife and kids; a cousin sentenced to prison for armed robbery; a paranoid uncle mistrustful of the government and imagined enemies; a sister who got pregnant at the age of fourteen and out of wedlock.

We were all lumped into the category of "Asian," and it has taken me years as a teacher, researcher, and scholar in the field of education to fully understand the scope and magnitude of what it means to exist as a Southeast Asian refugee in this society. Often unspoken in our very own homes, teachers' lounges, academic conferences, and educational policy circles are the ways Southeast Asian refugee youth contend with a distinct set of issues that separates us from Asian immigrant students writ large: the legacy of war - the root of our displacement - and its toll on life at the time and even generations later, after the war(s) have ended. The Vietnamese-American Pulitzer author, Dr. Viet Thanh Nguyen states, "All wars are fought twice, the first time on the battlefield, the second time in memory" (Nguyen, 2013, p. 144).

For some of us 1.5 generation refugees, the remnants of war enshroud our families and are encoded in our own bodies, even though we may have never lived through nor witnessed the atrocities firsthand or even stepped foot on our motherland. A few years ago, I stumbled across a news article regarding epigenetics: empirical studies (Henriques, 2019) point to evidence of how trauma alters the genetic makeup of survivors (e.g. war, famine, genocide, slavery, land theft), and consequently, passes along these genes to their descendants. The American War (that is what the Vietnamese refer to it as) may have ended in 1975, but its legacy lives on in the survivors and their children. My mother, who is much more forthcoming in sharing her lived experiences growing up in war time than my father, once shared with me seeing mangled, dead bodies splayed on trees as a child. She mentioned that she will never forget the smell - the smell of dead bodies. When I hear these stories from my mom, I wonder: how does one continue to live when you have witnessed the unspeakable? How must it have been for her as an adolescent to experience this? And yet, there was no time, no money, and no opportunity to process what she experienced. My mother is the strongest person I know. Growing up in a refugee household, I was taught that life is about suffering, and you do what you need to do in order to survive.

Bridging commonalities and solidarities with other racial groups, I cannot help but draw parallels to the many minoritized youth (e.g. Black, Latinx, Southeast Asian and Pacific Islander) I taught in Richmond, California, who had witnessed drive-by shootings or friends getting gunned down right in front of them. Where are the mental health counselors for these young people? Where is that necessary support to heal the trauma? A distinction I want to draw however is the PostTraumatic Stress Disorder (PTSD) remains concurrent for many youth growing up in disenfranchised communities, meanwhile soldiers and survivors get to leave war-torn countries.

I have witnessed firsthand the effects of PTSD amongst elders in the Southeast Asian community who have directly experienced war, but also from their descendants as well. As a member of the 1.5 generation, I have witnessed countless family members and friends struggle with the consequential epigenetic effects of PTSD as they deal with unaddressed mental health disorders, anxiety and depression. Despite the pandemic nature of the mental health crisis in 
Southeast Asian communities, largely we do not like to talk about it. We sweep it under the rug. We ignore it, perhaps all in the name of self-preservation. Because to confront these pains and these memories might be far too much for any one of us alone to handle. And as a society, when we essentialize Asians as a racial group, meting out a monolithic treatment to all, from our educational policies to public perception, then we are ignoring their full humanity and denying them opportunities for complete actualization.

Oddly enough, when I entered college and learned about the model minority myth (MMM) (Lee, 2015; Ngo \& Lee, 2007), I was completely baffled because so many of the Southeast Asian youth I grew up with appeared antithetical to this stereotype (Dao, 2014; Keo \& Noguera, 2018). In retrospect, however, I can see how I benefited from the MMM while a student at Oakland High with $100 \%$ students of color, where half the population identified as Asian and the rest split almost evenly between Black and Latinx students. In advanced placement and honors classes, enrollment heavily skewed towards Asian students. Many of us were of the 1.5 generation who started off school as English Language Learners, and yet, we occupied most of the AP classes offered at my high school. Conversely, most Black and Latinx students were relegated to basic or remedial courses. How was that possible? Rather than assessing students on their skill or ability, I surmise that the MMM informed an implicit bias amongst teachers at Oakland High where Asian students were perceived as well-behaved and academically-oriented, thus deserving of entry into these college preparatory courses. The statistics for my graduating class were staggering: there were 900 students who entered Oakland High with me as a sophomore and only 300 of us walked across the stage to graduate.

Once I left Oakland to pursue higher education and encountered other Asian-Americans, I realized that, first of all, we were definitely not a monolithic group. Furthermore, I am continually reminded that the invisible hand of the MMM continues to shadow my sense of (dis)placement and (in)visibility, even on this journey for tenure and promotion in the academy.

\section{To the Ivory Towers of Higher Education}

I entered UC Berkeley (Cal) as an undergraduate the same year admissions adhering to Proposition 209 came into effect - this law, the brainchild of Ward Connerly, a UC Regents' board memberessentially eliminated any race-based admissions from the University of California system. Consequently, the admissions of Asians skyrocketed at Cal; meanwhile Black and Latinx populations plummeted. In college, I met lots of Asian-Americans, many of whom I had very little in common with: they were affluent Asians who grew up in the suburbs and came from highlyeducated families. Some drove Beamers while others bought $\$ 600$ boots at the drop of a hat: I met Asians who had never heard of Federal Student Application for Financial Aid (FASFA). I even encountered some Vietnamese-Americans, self-identified as "boat people," who had collegeeducated parents and experienced upward mobility in their homeland and/or in this country, unlike my parents and most of my community back in Oakland. Needless to say, I often felt out of place amongst this sea of Asian faces. Furthermore, similar to many low-income, first-generation students, I struggled academically in my first two years at Cal and even contemplated dropping out after receiving a D on a Macbeth paper during my sophomore year. When I entered Cal, there was no Summer Bridge offered to ease my transition from high school to college nor were there academic advisors to provide guidance beyond an obligatory meeting to declare one's major. Perhaps I was overlooked because outwardly I did not count as a member of an underrepresented group. For most of my time at Cal, I was subjected to a sink or swim approach. With the guidance 
of one of my Graduate Student Instructors coupled with tutoring from the writing center, I eventually developed the writing skills that would buoy me in and through Berkeley. With a combination of luck, persistence, opportunity, and skills, I managed to graduate from Cal with an English Literature degree and a minor in education.

After spending most of my 20s teaching, I left the Bay Area for the first time in my life (beyond vacations and travel) at the age of thirty-two with my husband and three-month old son, so I could attend graduate school in the Midwest. In an educational leadership program, I immediately felt drawn to sociocultural courses that focused on issues of race. I found these topics fascinating, along with theories that could explain and help me make sense of how race functions in society. However, in private with other Asian or Latinx students, we sometimes wondered where our stories or histories were within this Black and white binary would surface. If we were lucky, we spent a day on the model minority myth or a brief reading on Asian American Crit Lit. The paucity of intellectual work on Asian-Americans in the content of my graduate program, let alone Southeast Asian students, left me frustrated.

Now as an assistant professor in an educational leadership program, I find myself guilty of the same critiques I leveled at my doctoral coursework. Over the arch of my academic career, thus far, as a Southeast Asian female scholar who writes and teaches about race, I have reconciled the Black-white binary: fully understanding institutionalized racism in this country hinges on recognizing and acknowledging the ways antiblackness permeates all facets of society. Once we become aware of how antiblackness racism functions in a white supremacist culture, then we may begin to offer a nuanced and complicated understanding of how Asians, Latinx, and Indigenous folks fit (or not) into this paradigm. Although these entities are not mutually exclusive, this is how I have made sense of the Black and white binary - as an entry point for me to understand how institutionalized racism operates in the United States.

Navigating the tenure-track (T\&T) as a Southeast Asian scholar has had its challenges. For one, there are very few educational scholars of Asian descent; it becomes even more narrow within my specific field. Similar to my experiences at Berkeley, being Asian does not automatically engender community or fictive kinship (Foster, 2005). At my institution, there is a La Raza faculty to organize around issues that impact and affect the Latinx community; I have seen La Raza faculty nurture and support junior Latinx faculty. Considering the dearth of Latinx faculty on the T\&T, the outreach and support of Latinx scholars is critical and necessary. Conversely, I am also aware of the adage that skin folk does not equate to kinfolk. Meaning, there are also factions and alliances within an ethnic and/or racial group at any institution. I once spoke to a Black faculty member at my institution; he asked me if there was a committee of Asian faculty that welcomed me to this institution. I laughed at his question because there might be Asian faculty here at my institution, primarily in the hard sciences, but it does not necessarily mean we are organized enough or at a place to build community. I have often wondered why this is the case amongst Asian academics at my institution but also across the country. Are there organized spaces for Asian faculty to build solidarities, especially in the field of education? If so, how come I haven't heard about it? But I sometimes wonder, even with an organized Asian faculty, how much would I have in common with these people? How much of a solidarity would there be considering the heterogeneity of the Asian diaspora and how disparate our experiences truly are?

Given my training and consciousness regarding race, I often wonder about how I am perceived at my institution and in my field as a whole being Southeast Asian. Using an intersectional lens, as a petite Asian female, I am also aware of the stereotypes about Asian women being docile and submissive (Crenshaw, 1990). When I started my T\&T job, I was advised to not 
speak up in faculty meetings as a junior scholar for a host of reasons. And for the most part, I do not. But in not speaking up, because I am deathly afraid of how I will be (mis)interpreted, coupled with my vulnerable status as an untenured faculty member, I wonder if I am reifying the Asian female stereotype. I am also a mother-scholar with young children. Considering the statistics of women of color securing tenure, let alone mother-academics, I am cognizant that the odds are very much against me (Mason, 2013). Given the constraints, from an institutional perspective and also grounded in (implicit) biases due to my intersectional identities, I wonder if my way of acting and behaving now as a junior faculty has sown the seeds about my capacity to be a leader at my institution and in my field amongst colleagues. Similar to every other industry in this country, the bamboo ceiling exists in the academy where Asian scholars are not perceived as leaders (Li, 2014). I have been advised that ultimately my publications and productivity as a scholar will dictate the trajectory of my academic career; however, I cannot help but also recognize that bias (Eberhardt, 2019), whether intentional or not, will have a hand in limiting how far I will go as a Southeast Asian female academic.

Despite the limitations and constraints I experience in the academy, I am fortunate that I have a supportive village of junior and senior scholars in my life. These scholars-across racial lines - continually support my academic journey from graduate school and currently on the tenure track. I am heartened by all the academics at my institution and across the country who have buoyed my confidence, believing in me enough to invest their own time and energy despite my episodic battles with the imposter syndrome: taking a phone call from me to talk through a grant proposal; inviting me to be a part of conference panels; co-authoring peer-reviewed papers; mentoring me through the labyrinths of my institution; writing me letters of support for the job market; reviewing my manuscripts before I submit them to a journal; answering my basic questions about a departmental or institutional policy. These white, Black, Latinx, Indigenous and Asian scholars from across the country and within my own institution and department have made a point to support me and my work, and for that, I am grateful.

\section{Conclusion}

Just the other day, I picked up an educational text where the author described the term minoritized youth, defined as racial groups who have been "minoritized" due to experiences related to structural racism and oppression; the author continued to explicitly list Black, Latinx and Indigenous students as minoritized youth. Instinctively, the absence of Asian, let alone Southeast Asian and Pacific Islander students, irked me. We continue to be invisible despite the extant educational literature on Southeast Asian youth (Dao, 2014; Iwamoto \& Liu, 2010; Keo \& Noguera, 2018; Lee, 2015; B. M. D. Nguyen et al., 2019; Poon \& Cohen, 2012; Takaki, 2012), which point to the fact that we are, in fact, also minoritized. And yet scholars in the field continually omit our existence from educational research, policy and reform efforts, from K12 all the way to higher education. Perhaps this omission derives from a lack of knowledge about the Asian American diaspora or points to the power of the model minority myth in masking the inequities that Southeast Asian youth confront in this country. My hope with sharing my story, from refugee camps to the academy, is to offer just one counter-narrative of the Southeast Asian experience that could potentially contribute to a broader and more complex understanding of the Asian-American experience. With the emergence of more Southeast Asian scholars and writers (Bui, 2017; B. M. D. Nguyen et al., 2016; Nguyên, 2010; V. T. Nguyen, 2015; Phi, 2017; Vuong, 
2014) who speak up and out about the experiences of Southeast Asian refugees, perhaps we can gradually shine a light at the enduring myth that shadows us all.

\section{References}

Bui, T. (2017). The nest we could do: An illustrated memoir. Abrams.

Crenshaw, K. (1990). Mapping the margins: Intersectionality, identity politics, and violence against women of color. Stanford Law Review, 43, 1241.

Dao, L. (2014). Refugee representations: Southeast Asian American youth, hip hop, and immigrant rights. Amerasia Journal, 40(2), 88-109.

Foster, L. (2005). The practice of educational leadership in African American communities of learning: Context, scope, and meaning. Educational Administration Quarterly, 41(4), 689700.

Iwamoto, D. K., \& Liu, W. M. (2010). The impact of racial identity, ethnic identity, Asian values, and race-related stress on Asian Americans and Asian international college students' psychological well-being. Journal of Counseling Psychology, 57(1), 79-91. https://doi.org/10.1037/a0017393

Keo, P. T., \& Noguera, P. A. (2018). From the margins to the center: Debunking claims about Southeast Asian American masculinity. Equity \& Excellence in Education, 51(2), 199216.

Lee, S. J. (2015). Unraveling the “model minority” stereotype: Listening to Asian American youth. Teachers College Press.

Li, P. (2014). Hitting the ceiling: An examination of barriers to success for Asian American women. Berkeley Journal of Gender Law \& Justice, 29, 140.

Ngo, B., \& Lee, S. J. (2007). Complicating the image of model minority success: A review of Southeast Asian American education. Review of Educational Research, 77(4), 415-453.

Nguyen, B. M. D., Nguyen, M. H., Chan, J., \& Teranishi, R. T. (2016). The racialized experiences of Asian American and Pacific Islander students: An examination of campus racial climate at the University of California, Los Angeles.

Nguyen, B. M. D., Noguera, P., Adkins, N., \& Teranishi, R. T. (2019). Ethnic discipline gap: Unseen dimensions of racial disproportionality in school discipline. American Educational Research Journal, 56(5), 1973-2003.

Nguyên, T. S. T. (2010). Vietnamese diasporic placemaking: An ethnographic moment in uneven geographic development. Educational Policy, 24(1), 159-188.

Nguyen, V. T. (2013). Just memory: War and the ethics of remembrance. American Literary History, 25(1), 144-163.

Nguyen, V. T. (2015). The sympathizer: A novel (Pulitzer Prize for fiction). Grove/Atlantic, Inc.

Phi, B. (2017). A different pond. Capstone.

Poon, O., \& Cohen, J. (2012). Youth participatory action research and the future of education reform. Journal of Critical Thought and Praxis, 1(1), 10.

Takaki, R. (2012). Strangers from a different shore: A history of Asian Americans (updated and revised). eBookIt. com.

http://books.google.com/books?hl=en\&lr=\&id=mt_tw5cn8y0C\&oi=fnd\&pg=PT10\&dq= strangers+from $+\mathrm{a}+$ different + shore $\&$ ots $=q$ txs YvaD3s\&sig=-

SL_O9thctgOPysQtW8twE0gAY4

Vuong, O. (2014). On earth we're briefly gorgeous. Poetry, 205(3), 244-247. 


\begin{abstract}
About the Author

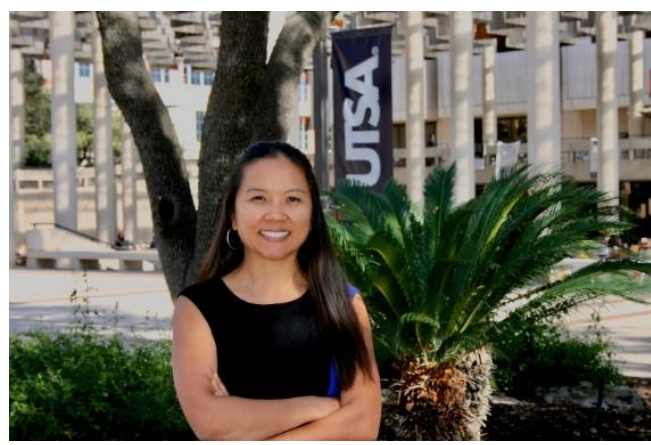

Van T. Lac, is an assistant professor at the University of Texas at San Antonio in the department of Educational Leadership and Policy Studies. She earned her doctoral degree at the University of Wisconsin-Madison in Educational Leadership and Policy Analysis. Prior to her graduate studies, she was a high school English teacher for eight years in Richmond, California. Her research interests include how educational leaders leverage participatory action research working alongside minoritized youth and how K12 teachers, school leaders, and students develop or strengthen their racial consciousness. Her research has been published in peer-reviewed journals, such as Urban Education, Urban Review, and Journal of Research on Leadership Education.
\end{abstract}




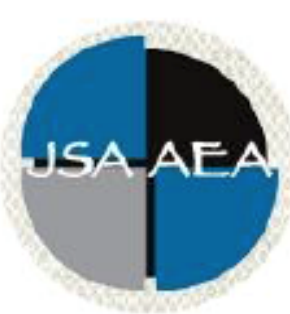

Vol. 15 Iss. 2 Special Issue (2020) Www.JSAAEA.org

Special Issue Co-Editors

Dr. Peter T. Keo

Stanford University

Dr. Loan Thi Dao

St. Mary's College of California

Editor

Dr. Wayne E. Wright

Purdue University

Associate Editors

Dr. Chhany Sak-Humphry

University of Hawaii at Manoa

Dr. Phitsamay Sychitkokhong Uy

University of Massachusetts, Lowell

\author{
Book Review Editor \\ Dr. Vichet Chhuon \\ University of Minnesota \\ Creative Works Editor \\ Bryan Thao Worra \\ Lao Assistance Center \\ Journal Manager \\ Fang Gao \\ Purdue University
}

\title{
Editorial Review Board
}

Dr. Steve Arounsack

California State University, Stanislaus

Dr. Sovicheth Boun

Salem State University
Dr. Carl L. Bankston III

Tulane University

Dr. Phala Chea

Lowell Public Schools 


\author{
Dr. Virak Chan \\ Purdue University \\ Dr. Loan Dao \\ St. Mary's College of California \\ Dr. Changming Duan \\ University of Missouri-Kansas City \\ Dr. Sothy Eng \\ Lehigh University \\ Dr. Vincent K. Her \\ University of Wisconsin, Eau Claire \\ Dr. Peter Nien-Chu Kiang \\ University of Massachusetts, Boston \\ Dr. Kevin K. Kumashiro \\ University of Illinois, Chicago \\ Dr. Ha Lam \\ Independent Scholar \\ Dr. Jonathan H. X. Lee \\ San Francisco State University \\ Dr. Monirith Ly \\ Royal University of Phnom Penh \\ Dr. Bic Ngo \\ University of Minnesota \\ Dr. Leakhena Nou \\ California State University, Long Beach \\ Dr. Mark Pfeifer \\ SUNY Institute of Technology \\ Dr. Loan T. Phan \\ University of New Hampshire \\ Dr. Karen Quintiliani \\ California State University, Long Beach \\ Dr. Angela Reyes \\ Hunter College \\ The City University of New York \\ Dr. Fay Shin \\ California State University, Long Beach \\ Dr. Christine Su \\ College of San Mateo \\ Dr. Alisia Tran \\ Arizona State University \\ Dr. Khatharya Um \\ University of California, Berkeley \\ Dr. Kim Tran \\ University of California, Los Angeles, \\ Glendale Community College \\ Dr. Molly Wiebie \\ The University of Texas at Austin
}

Dr. George Chigas

University of Massachusetts, Lowell

Dr. Hien Duc Do

San Jose State University

Dr. Sophal Ear

Occidental College

Dr. Jeremy Hein

University of Wisconsin, Eau Claire

Dr. Nancy H. Hornberger

University of Pennsylvania

Dr. Peter Tan Keo

Stanford University

Dr. Yvonne Kwan

San Jose State University

Dr. Ravy Lao

California State University, Los Angeles

Dr. Stacey Lee

University of Wisconsin, Madison

Dr. Sue Needham

California State University, Dominguez Hills

Dr. Max Niedzwiecki

Daylight Consulting Group

Dr. Clara Park

California State University, Northridge

Dr. Giang Pham

University of Massachusetts Amherst

Dr. Malaphone Phommasa

University of Clifornia Santa Barbara

Dr. Kalyani Rai

University of Wisconsin-Milwaukee

Dr. Cathy J. Schlund-Vials

University of Connecticut, Storrs

Dr. Nancy J. Smith-Hefner

Boston University

Dr. Yer J. Thao

Portland State University

Dr. Monica M. Trieu

Purdue University

Dr. Silvy Un

Saint Paul Public Schools

Dr. Linda Trinh Vo

University of California, Irvine

Dr. Yang Sao Xiong

The University of Wisconsin-Madison

Dr. Zha Blong Xiong

University of Minnesota 


\section{Doctoral Student Editorial Review Board}

\author{
Diana Chandara \\ University of Minnesota-TwinCiteis \\ Linh Dang \\ University of Rochester \\ Annie BichLoan Duong \\ San Joaquin County Office of Education \\ Jacqueline Mac \\ Indiana University \\ Vanessa Sovanika Na \\ University of California SanDiego \\ Khoi Nguyen \\ George Mason University \\ Linda Marie Pheng \\ University of Wisconsin-Madison \\ Latana Thaviseth \\ University of California Los Angeles \\ Melissa Vang \\ San Diego State University \\ Soua Xiong \\ San Diego State University \\ Claremont Graduate University
}

\author{
Kassandra Chhay \\ University of Minnesota-Twin Cities \\ Bao Diep \\ University of Minnesota-Twin Cities \\ Nielson Hul \\ Cornell University \\ Dung Minh Mao \\ University of Minnesota-Twin Cities \\ Hoa Nha Nguyen \\ Boston College \\ Thien-Huong Ninh \\ University of Southern California \\ Krissyvan Truong \\ Claremont Graduate University \\ Mai Vang \\ University of Massachusetts Boston \\ Thong Vang \\ University of Minnesota-Twin Cities
}

